Отримано: 25 листопада 2019 р.

Прорецензовано: 05 грудня 2019 р.

Прийнято до друку: 10 грудня 2019 р

e-mail: annaklymenko96@gmail.com

DOI: $10.25264 / 2311-5149-2019-15(43)-4-8$
Tatyana Grynko, Anna Klymenko. Ensuring the economic security of economic entities: a personnel component. Наукові записки Національного університету «Острозька академія». Серія «Економіка» : науковий журнал. Острог : Вид-во НаУОА, грудень 2019. № 15(43). C. 4-8.

\title{
ENSURING THE ECONOMIC SECURITY OF ECONOMIC ENTITIES: A PERSONNEL COMPONENT
}

The article deals with the problems of ensuring economic security of the enterprise in terms of personnel security in the context of personnel motivation. The tendency of motivation influence on the system of economic security was investigated. The concept of "economic security" and approaches to the definition of "motivation" are considered. Different types of motivation are offered, including intangible ones, which will increase the level of economic security at the enterprise.

Key words: motivation, personnel, system, economic security.

Гринько Тетяна Валеріївна,

Професор, доктор економічних наук, Декан факультету економіки

Дніпровський національний університет імені Олеся Гончара

Клименко Анна Олександрівна,

Дніпровський національний університет імені Олеся Гончара

\section{ЗАБЕЗПЕЧЕННЯ ЕКОНОМІЧНОЇ БЕЗПЕКИ ЕКОНОМІЧНИХ СУБ'ЄКТІВ: КАДРОВИЙ КОМПОНЕНТ}

У статті досліджено проблеми забезпечення економічної безпеки підприємства в аспекті кадрової безпеки в розрізі мотивації персоналу. Охарактеризовано тенденцію впливу мотивачії на систему економічної безпеки. Розглянуто поняття економічної безпеки та підходи до трактування мотивації. Запропоновано різні види мотивації, зокрема нематеріальні, які підвищать рівень економічної безпеки на підприємстві.

Ключові слова: мотивачія, персонал, система, економічна безпека.

Гринько Татьяна Валерьевна,

Профессор, доктор экономических наук, Декан факультета экономики Днепровский национальный университет имени Олеся Гончара

Клименко Анна Александровна, Днепровский начиональный университет имени Олеся Гончара

\section{ОБЕСПЕЧЕНИЕ ЭКОНОМИЧЕСКОЙ БЕЗОПАСНОСТИ ЭКОНОМИЧЕСКИХ СУББЕКТОВ: КАДРОВЫЙ КОМПОНЕНТ}

В данной статье мы исследовали вопрос кадровой безопасности как составляющей экономической безопасности в разрезе мотивачии персонала. Было схарактеризировано тенденцию влияния мотивации на систему экономической безопасности. Рассмотрено понятие «экономической безопасности» и подходы к определению «мотиваџии». Предложено разные виды мотивации, в том числе и нематериальные, которые повысят урівень безопасности на предприятии.

Ключевые слова: мотивачия, персонал, система, экономическая безопасность.

Target setting. In the current conditions in Ukraine and in the world there is an acute problem concerning the formation of an effective and efficient system of motivation at enterprises. Every year there are more and more freelancers and self-employed persons and enterprises have problems with the "outflow" of employees to competing enterprises, which negatively affects the economic security of the business entity. 
Analysis of recent research and publications. In recent years, more and more scientists are exploring methods, tools and mechanisms for the formation of the motivation system as a component of the economic security of the enterprise.

Having analyzed the scientific works of Ukrainian and foreign scientists, such as A. Dykyi, A. Yepifanov, A. Hrunin, O. Bilous, F. Khmil and others, we can conclude that the motivation of employees in the enterprise management system is an important element in the system of economic security of the enterprise and its development.

A. Odyntsov studied the economic security of the enterprise and its role in the economic system of Ukraine and believed that economic security depends on the stability of the operation of the enterprise and that no one would cause damage to the business entity[3]; V. Shlykov researched personnel security and emphasized on individual classifications of employee safety[2]; I. Shvets paid attention to the study of risks arising at each stage of interaction between the employee and the enterprise, the assessment their probability and methods of prevention[2]; A. Dykyi investigated motivation at enterprises in the aspect of intangible incentives[1]. However, this problem is relevant and requires more in-depth research.

The purpose of the article is to develop directions for improving the motivation and suggestions for improving the economic security of the business entity.

Presentation of the main research material. Today, an important prerequisite for the development of modern society is the provision of an effective system of motivation at the enterprise, which creates conditions for economic growth and competitiveness in terms of maximum use of innovations for the individual employee and the enterprise as a whole, as well as guarantees its economic security. In order to determine the aspects that are important for a manager to create motivated personnel, it is necessary, first of all, to determine the basic scientific approaches to the essence of the concept of "economic security" and "motivation at the enterprise".

Table 1.

Scientific approaches to the definition of "Economic security"

\begin{tabular}{|c|l|l|}
\hline No. & \multicolumn{1}{|c|}{ Author } & \multicolumn{1}{|c|}{ Interpretation } \\
\hline 1 & A. P. Dykyi [1] & $\begin{array}{l}\text { Economic security of the enterprise as ensuring conditions of preservation of its property and trade } \\
\text { secrets }\end{array}$ \\
\hline 2 & Ya. V. Sokolov[1] & Ensuring the conditions for the preservation of trade secrets and other sectors of the enterprise \\
\hline 3 & A. A. Odyntsov[3] & $\begin{array}{l}\text { A state of civilized business in which there is no economic or other damage that would be inflicted } \\
\text { on business intentionally or not intentionally by individuals or social organizations }\end{array}$ \\
\hline 4 & V. V. Bielokurov[1] & $\begin{array}{l}\text { Compliance of material, financial, personnel, technical and technological potentials and } \\
\text { organizational structure of the enterprise with its strategic goals and objectives }\end{array}$ \\
\hline 5 & V. V. Shlykov [2] & $\begin{array}{l}\text { State of protection of vital interests of the enterprise from real and potential sources of danger or } \\
\text { economic threats }\end{array}$ \\
\hline 6 & A. O Yepifanov[3] & $\begin{array}{l}\text { The ability of the enterprise to effectively and stably carry out economic activities by using a set of } \\
\text { interrelated diagnostic and control measures of a financial nature. }\end{array}$ \\
\hline 7 & $\begin{array}{l}\text { D. Kovalov, } \\
\text { T. Sukhorukova [4] }\end{array}$ & The state of protection of the enterprise activity from negative environmental influences \\
\hline 8 & O. A. Hrunin[4] & $\begin{array}{l}\text { The state of the enterprise in which it, with the most efficient use of corporate resources, achieves } \\
\text { the prevention, mitigation or protection against existing dangers and threats and ensures the } \\
\text { achievement of business goals in the conditions of competition and entrepreneurial risk }\end{array}$ \\
\hline
\end{tabular}

After analyzing Table 1, we can make a number of generalizations that will help to understand more about this category:

- in order to achieve business goals, important corporate resources are the most effective in matters of economic security;

- the enterprise is influenced by both external and internal environment: starting with the business model and ending with competing companies;

- for the enterprise and its employees, the most important is the protection against external factors.

Based on this study, we can propose the following definition of economic security, that is, an enterprise in a state of balance of its components, such as finance, technology and people, in which it generates the most possible profit and operates without internal and external threats.

Let's consider in more detail the functional components of the economic system of the enterprise, namely, financial, intellectual and personnel, technical and technological, political and legal, information, environmental and power [5].

There is also a certain hierarchy between these components, which distinguishes three main elements: financial security, personnel security and information security. 
In the course of the study, it is necessary to consider in more detail the personnel and information security that directly interact with each other and depend on employees and their motivation.

It should be noted that the most important thing at the enterprise is knowledge and information, because they can help to develop it, or vice versa to bankrupt. In today's world, almost all information is on digital media and is not available. However, even the most automated enterprises have specialists who manage all processes and mechanisms. At medium and large enterprises, separate departments are created that ensure the integrity and security of information on the life cycle of the enterprise and the information system as a whole. Wherefrom, it can be concluded that all commercial data, financial data and other information about the company is in hands of hired employees who can use it in bad faith, what is why the issue of trust in employees and in general personnel safety is very relevant.

Personnel security should be considered as a set of certain elements that interact with each other and ensure its integrity (Fig. 1).

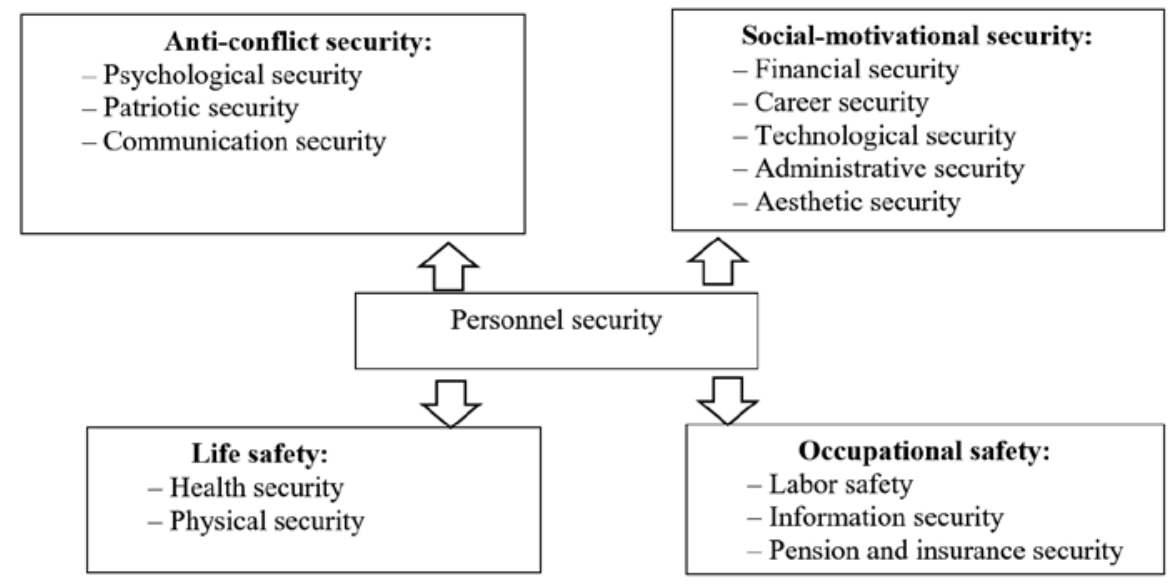

\section{Figure 1. Components of personnel security as a lever of interaction of motivation in the economic security system [5]}

All four of the above components are required for complete security of the enterprise personnel, but there are also factors of threat to personnel security, which can be divided into external and internal.

External factors are conditions of motivation at competing enterprises; "enticement" of employees; attraction of employees to dependence on competitors; inflation and a wage level.

Internal factors are mismatch of qualification to the position; lack of personnel evaluation system; inefficient motivation system; lack of creative elements in the work; lack of corporate culture.

Henceforth, we will focus on the external factors of the threat to personnel security, which is a major component of economic security, since people can influence any of its other elements.

As of today, in Ukraine there is a tough struggle between enterprises for employees. In particular, in the Dnipropetrovsk region in 2018, there are approximately 12 companies per employee with 5 years' experience in one industry [6].

That is, "enticement" of decent personnel is an urgent problem of many enterprises in Ukraine, as it is a threat to both the ordinary performance of the tasks assigned to employees and the competence of employees, and to the economic security of the enterprise.

The so called hunting of employees occurs for two reasons:

- search for the best employees;

- obtaining secret information about the competing enterprise.

In order to prevent information "leakage", many enterprises use the practice of signing a Non-disclosure document, which is called NDA (Non-disclosure agreement), which points out what data cannot be disclosed under any circumstances and what consequences can be followed if terms of the document are violated.

Having analyzed the experience of Ukrainian enterprises concerning the signing of this document by employees, we can note that the disadvantages are associated with the psychological state of employees and the fact that they lose the motivation to keep secret and feel distrusted; and the positive are the legal security of non-disclosure of ideas, confidential information and compensation in the event of breach of this agreement.

Throughout the material, it is evident that motivation is a key element in ensuring the economic security of the enterprise. 
It should also be remembered that enterprises need to use a variety of methods of motivation, ranging from the usual praise, ending with financial reward.

Let's consider different mechanisms of motivation at enterprises (Table 2)

Tab. 2 .

Interpretation of the definition of "motivation" at the enterprise

\begin{tabular}{|c|l|l|}
\hline No & \multicolumn{1}{|c|}{ Author } & \multicolumn{1}{c|}{ Approach to determining employee motivation } \\
\hline 1 & A.S.Nemchenko[7] & $\begin{array}{l}\text { Ranking the needs of employees in the form of wages, working conditions, career prospects, } \\
\text { professional development, team atmosphere and relationships with management }\end{array}$ \\
\hline 2 & N. V. Iziumtseva[7] & Focus on financial motivation: the increase in wages, bonuses and social packages \\
\hline 3 & N. F. Aleksieieva [8] & Motivation of employees' performance and its financial component \\
\hline 4 & L. R. Kucher[7] & $\begin{array}{l}\text { Motivation by taking into account the goals of individual employees and individual approach to } \\
\text { determining the material and intangible components of motivation }\end{array}$ \\
\hline 5 & I.O. Shchukin [8] & $\begin{array}{l}\text { Complex use of economic (financial) and non-economic components of motivation on the basis of } \\
\text { motivational monitoring of performance of tasks by employees }\end{array}$ \\
\hline 6 & G. Kinderman [8] & $\begin{array}{l}\text { Application of target agreements between the enterprise and the employee and financial motivation } \\
\text { after achievement of these purposes }\end{array}$ \\
\hline
\end{tabular}

Hence, in order to ensure the personnel safety of the enterprise, it is necessary to use the following in addition to material motivation: recognition (the main thing is to thank in a timely manner for a job well done); involvement (an important source of employees motivation is the level of interest of the manager in their work; it is necessary to be periodically interested in how things are going in a particular project); a gift (to give a gift without a reason, just for a job well done); day off (if the employee did the work earlier than the scheduled time, it would be advisable to offer him to take a day off); acknowledgement (to write a letter of thanks and add "a copy" to colleagues or make it public at the meeting).

Therefore, at the heart of the uninterrupted activity of the enterprise, that is, its protection from the internal and external environment, that is, its economic security, there are people who need to be properly and effectively motivated to achieve maximum results.

Conclusions. The economic security of the enterprise in terms of personnel is a system in which an employee may, under certain circumstances, become a victim of it or create a real threat to the organization. Above all, the economic security of the business entity depends directly on the sense of security of employees, job satisfaction and job position, as well as motivation and belonging to the enterprise as a whole.

A qualitatively developed system of personnel motivation ensures the economic security of the individual, which ultimately affects the economic security and success of the enterprise where he works.

Investigating this problem, we have established the interaction of employees' motivation in the system of economic security by a phased study of the components of economic security.

In order to ensure the system of motivation it is necessary to correlate material and moral remuneration of employees, to create safe working conditions, to create conditions for timely career growth of personnel, to use personnel planning at enterprises, to encourage employees to express ideas for business development, so that they can feel their belonging to the company in full; to create differentiation of motivation of employees and their income.

In general, motivated employees are the key to guaranteeing the stability and competitiveness of the business entity, as well as its rapid development and success in the future.

\section{References}

1. Bielousova I.A. Management Accounting - information component of the enterprise economic security system: [monograph]. K.: Dorado-Print, 2018. 432p.

2. Lysenko Yu.G. Mechanisms of economic security management / Lysenko Yu.G., Lopatovsky V.G. The concept, classification of risks and methods of combating them. Bulletin of the Podillya Technological University. 2017. № 4.4.1. T.1. Pp. $177-180$.

3. Odyntsov A.A. Economic and information security of entrepreneurship: manual for universities.M.:"Academy". 2018. $336 \mathrm{p}$.

4. Economic security of enterprises, organizations and institutions: manual / [V. L. Ortynskyi, I.S. Kernytskyi, etc.] K.: Legal unity, 2016. 544 p.

5. Sosnovska I.M. The concept and importance of economic security of production and economic activity of enterprises. Effective Economics. 2015. № 9. Access mode: http://www.economy.nayka.com.ua/?op=1\&z=43

6. Number of enterprises and unemployed in Dnipropetrovsk region. URL: http://www.ukrstat.gov.ua. (date of appeal 10.09.2019). 
7. Nemchenko A.S., Yurchenko H.M., Zhyrova I.V. Analysis of motivational principles in the personnel management of pharmaceutical organization. Management and economics of formation // Management, economy and quality assurance in pharmacy. 2011. № 1. pp. 18-23.

8. Semykina M.V. New paradigm of labor motivation in the system of development of social-labor relations // Economy and Management. 2018. № 3. P. 111-117.

9. Grynko T. Tangible and intangible rewards in service industries: Problems and prospects. Journal of Applied Economic Sciences, 2018. 12(8). P. 2481-2491.

10. Grynko T.V. Theoretical and methodological aspects of the economic safety assessment of the enterprise. Black Sea Economic Studies, 2019. Pub. 41. P. 94-99. 